Volume 1, Number 2, 2015

\title{
Simulation of Dynamic Processes of Gas Flow in Collector Systems
}

\author{
Leonid Lesovoy ${ }^{*}$, Volodymyr Kuzyk \\ Lviv Polytechnic National University, S. Bandery St., 12, Lviv, 79013, Ukraine
}

Received: November 16, 2015. Revised: December 08, 2015. Accepted: December 15, 2015.

(C) 2015 The Authors. Published by Lviv Polytechnic National University.

\begin{abstract}
By using CFD-simulation, plug length simulation of local resistance type plugged tee, which changes the flow direction, using equations of hydrodynamics was carried out. During simulation, velocity of medium in the thread of the collector system in which local input resistance was plugged tee, which changes the flow direction, was measured. Herewith for determination of this velocity and reduction of its distortion collector system simulation at different plug lengths was carried out. Plug lengths of local resistance type plugged tee, which changes the flow direction, where the distortion of flow rate diagram disappears, were determined. The equation for calculating length of the thread of the collector system to the place where distortion of gas flow rate disappears, to the plug length of local resistance type plugged tee, which changes the flow direction was obtained.
\end{abstract}

Keywords: natural gas; collector system; local resistance; gas flow; CFD-simulation.

\section{Definition of the problem to be solved}

Under the conditions of growth of prices for energy resources, increasing the accuracy of natural gas accounting is of great importance. Flow rate and volume of natural gas is measured by the differential pressure method according to the national standard of Ukraine DSTU GOST 8.586.2:2009 [1]. Collector systems which are located at the gas measuring stations are formed from straight sections of measuring pipeline and local resistance (knees, tees, etc.), that affect movement of flow in their threads. The collector systems which threads are located in one plane with the measuring pipeline have [1-4] the main local resistance (except valves) tees, that branch flow, and plugged tee, which changes the flow direction. The plugged tee, which changes the flow direction, is the final element in the flow rate diagrams formation. This local resistance depending on its construction can significantly distort the flow before narrowing device and thereby affect the accuracy of measurement of the flow rate. Therefore simulation of local resistance and research speed processes therein is an actual task.

\section{Analysis of the recent publications and research works on the problem}

The distance at which the plug should be placed in the tee, which changes the flow direction, in the normative documents for measuring flow rate and volume of natural gas aren't described $[1,2,5,6]$. Depending on the plug length flow rate will be distorted and her interference will be carried.

\section{Statement of the goal of the paper}

To investigate the effect of plugged tee, which changes the flow direction, on the character of motion of the measured medium in the collector system threads. To get the equation for calculating length of the thread of the collector system to the place where distortion of gas flow rate disappears, to the plug length of local resistance type

\footnotetext{
*Corresponding author. Email address: techinfoflow@yahoo.co.uk
} 
plugged tee, which changes the flow direction, which will help reduce the impact of uneven flow of natural gas on the relative aggregate uncertainty of the outcome of the measuring flow rate and volume of natural gas in the collector systems at the gas measuring stations.

\section{Presentation and discussion of the research results}

The authors carried out research speed processes of the collector systems at the gas measuring stations that arise in the plugged tee, which changes the flow direction, using CFD-simulation [7, 8]. The collector system with $700 \mathrm{~mm}$ internal diameter $D_{B T}$ of the measuring pipeline and one thread of collector unit with $350 \mathrm{~mm}$ internal diameter $D_{H}$ of the measuring pipeline were selected for the calculation. The investigational plugged tee, which changes the flow direction, with plug length $L_{2 B T}$ of the plugged tee, which is $2 \cdot D_{B T}$, and the trajectory of the flow of natural gas inside were shown in Fig. 1. (see Fig. 1).

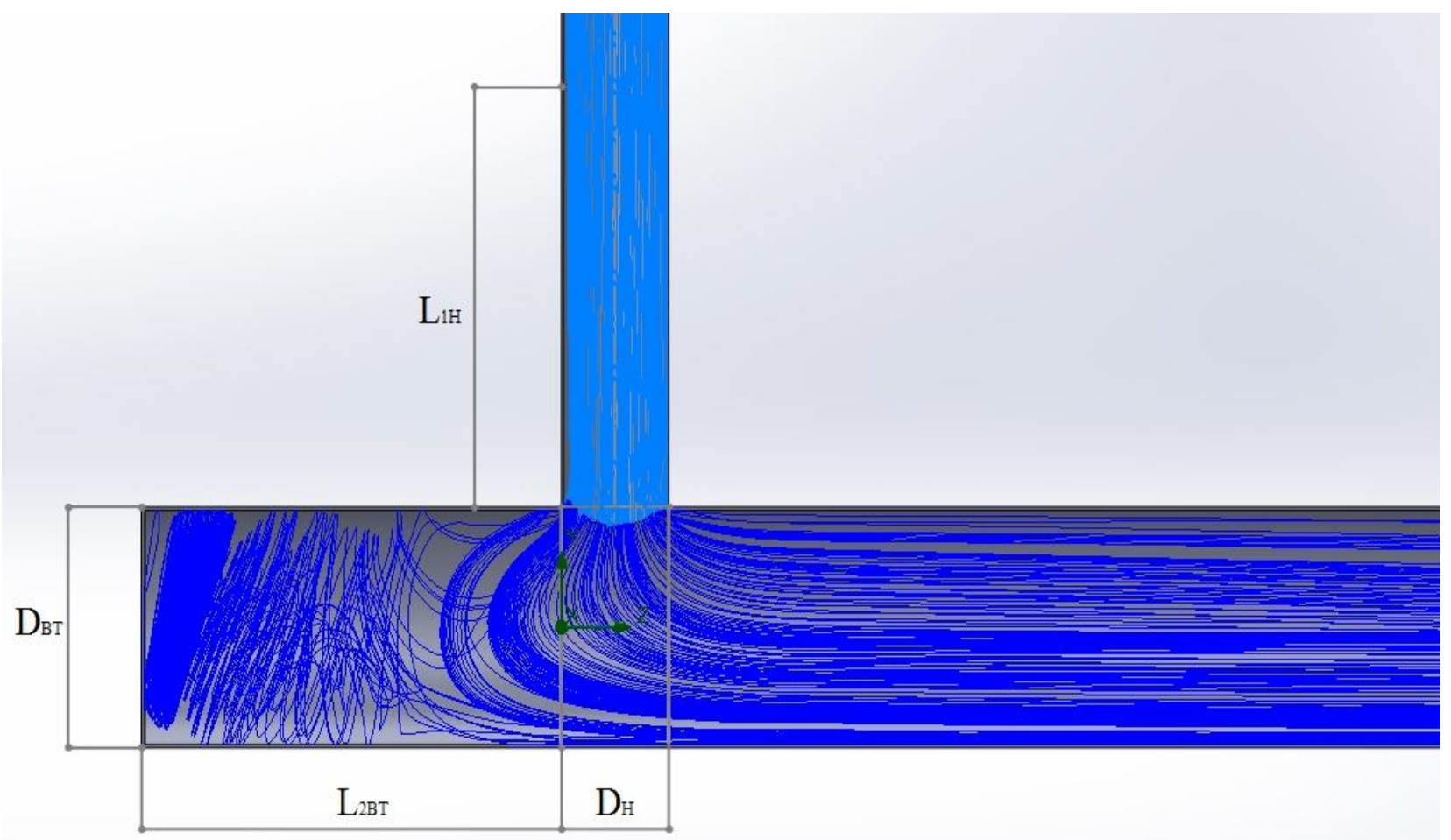

Fig. 1. The trajectory of the gas flow in the plugged tee, which changes the flow direction, with plug length which is $2 \cdot D_{B T}$

To study the flow in the plugged tee, which changes the flow direction, series of models with lengths of plug in the range of $0.25 \cdot D_{B T}$ to $4.00 \cdot D_{B T}$ with step $0.25 \cdot D_{B T}$ was established. For each of these models the length $L_{I H}$ of thread of the collector system to the place where distortion of natural gas flow rate disappears was determined.

According to the results of simulation, graph of the length $L_{1 H}$ of thread of the collector system to the place where distortion of natural gas flow rate disappears depending on plug length $L_{2 B T}$ of local resistance type plugged tee, which changes the flow direction, was obtained.

From the obtained curve we can see that with plug magnitude increasing, distance at which leak of natural gas is aligned decreases to a certain value and its further increase is inadvisable. Solution to obtain analytical dependence which allows calculating the length of straight section of the collector system thread which distortion of natural gas flow rate disappears which caused plugged tee, which changes the flow direction was adopted after analyzing the present graph.

In order to present dependence of plug size on the length of the straight section of the collector system thread which distortion of flow rate disappears in the collector system thread, we apply the relative length of the collector system thread to the place where the natural gas flow rate leveled, that is calculated by the equation 


$$
L_{1}=\frac{L_{1 \mathrm{H}}}{D_{\text {н }}},
$$

and the relative length of the plug at the local resistance plugged tee, which changes the flow direction, that is calculated by the equation

$$
L_{2}=\frac{L_{2 \mathrm{BT}}}{D_{\text {вт }}} .
$$

The function in the form of the type of hyperbole is selected to approximate

$$
\mathrm{Y}=\frac{\mathrm{a}}{\mathrm{X}}+\mathrm{b}
$$

where $Y$ is the relative length $L_{1}$ of thread of the collector system to the place where the natural gas flow rate leveled; $X$ is the relative length of the plug $L_{2}$ of the muffled tee, which changes the flow direction; $a, b$ is the coefficients of equation.

As a result of the calculation the value (see Table 1) of CFD-simulation process of the flow of natural gas in the plugged tee, which changes the flow direction, were obtained.

\begin{tabular}{|c|c|c|c|c|}
\hline \multirow{2}{*}{$\#$} & \multirow{2}{*}{$\begin{array}{c}\text { The relative length of } \\
\text { the plug at the local } \\
\text { resistance plugged tee, } \\
\text { which changes the flow } \\
\text { direction }\end{array}$} & \multicolumn{2}{|c|}{$\begin{array}{l}\text { The relative length of thread of the collector system to the place } \\
\text { where distortion of natural gas flow rate disappears }\end{array}$} & \multirow{2}{*}{$\begin{array}{c}\begin{array}{c}\text { Relative extended } \\
\text { uncertainty }\end{array} \\
U_{L 1}^{\prime}, \%\end{array}$} \\
\hline & & $\begin{array}{l}\text { Data obtained by CFD-simulation, } \\
\qquad L_{1}\end{array}$ & $\begin{array}{l}\text { Data calculated by the } \\
\text { equation (4), } L_{l}\end{array}$ & \\
\hline 1 & 0.25 & 15.7790 & 15.7550 & 0.15 \\
\hline 2 & 0.50 & 7.6255 & 7.5850 & 0.53 \\
\hline 3 & 0.75 & 4.7980 & 4.8617 & 1.32 \\
\hline 4 & 1.00 & 3.5679 & 3.5000 & 1.90 \\
\hline 5 & 1.25 & 2.7211 & 2.6830 & 1.40 \\
\hline 6 & 1.50 & 2.1443 & 2.1383 & 0.27 \\
\hline 7 & 1.75 & 1.7630 & 1.7493 & 0.77 \\
\hline 8 & 2.00 & 1.4525 & 1.4575 & 0.34 \\
\hline 9 & 2.25 & 1.2352 & 1.2306 & 0.37 \\
\hline 10 & 2.50 & 1.0514 & 1.0490 & 0.22 \\
\hline 11 & 2.75 & 0.8967 & 0.9005 & 0.42 \\
\hline 12 & 3.00 & 0.7635 & 0.7767 & 1.72 \\
\hline 13 & 3.25 & 0.6727 & 0.6719 & 0.11 \\
\hline 14 & 3.50 & 0.5902 & 0.5821 & 1.37 \\
\hline 15 & 3.75 & 0.4995 & 0.5043 & 0.96 \\
\hline 16 & 4.00 & 0.4342 & 0.4363 & 0.48 \\
\hline
\end{tabular}

Table 1. The value of the relative length of thread of the collector system to the place where disappears distortion of natural gas flow rate of CFD-simulation process and function value 
The coefficients $a$ and $b$ of equation (3) were calculated in the mathematical environment Matlab: $a=4.085$ and $b=-0.585$. Using the coefficients $a, b$ and equation (3) equation to calculate the relative length of thread of the collector system to the place where distortion of natural gas flow rate disappears to the relative length of the plug of local resistance type plugged tee, which changes the flow direction, was obtained in the form of

$$
L_{1}=\frac{4.085}{L_{2}}-0.585
$$

The graphs of dependence of the relative length of thread of the collector system to the place where distortion of natural gas flow rate disappears to the relative length of the plug of local resistance type plugged tee, which changes the flow direction, for data that were obtained from CFD-simulation and data which were calculated by the equation (4) are presented in Fig. 2.

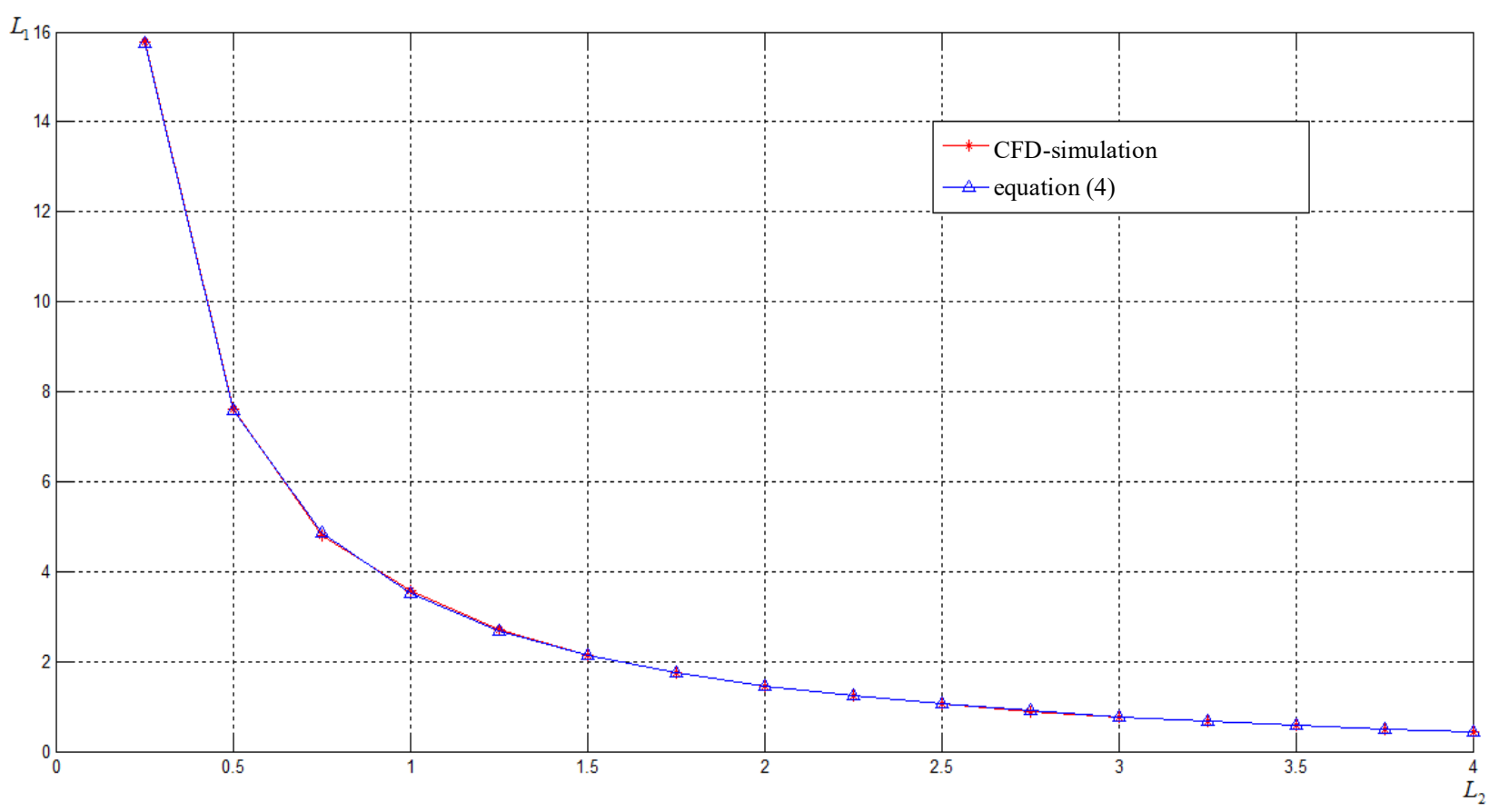

Fig. 2. Graphical comparison of calculation results based on equation (4) and CFD-simulation

Substituting in equation (4) dependences (1) and (2) after simple transformations, we obtain equation for calculating length of thread of the collector system to the place where distortion of natural gas flow rate disappears to the relative length of the plug of local resistance type plugged tee, which changes the flow direction, as

$$
L_{1 H}=\left(\frac{4.085 \cdot D_{6 m}}{L_{26 B}}-0.585\right) \cdot D_{H},
$$

To approximated curve which is shown in Fig. 2 will carry out the calculation of standard deviation $\sigma$ by the formula

$$
\sigma=\sqrt{\frac{1}{\mathrm{n}-1} \sum_{\mathrm{i}=1}^{\mathrm{n}}\left(\mathrm{L}_{1 \mathrm{i}}-\mathrm{L}_{\mathrm{c}}\right)^{2}},
$$


where $n$ is the sampling size; $L_{l i}$ is is element of sampling; $L_{c}$ is the arithmetic mean of sampling, which value is calculated by the equation

$$
\mathrm{L}_{\mathrm{c}}=\frac{1}{\mathrm{n}} \sum_{\mathrm{i}=1}^{\mathrm{n}} \mathrm{L}_{1 \mathrm{i}} \text {, }
$$

To approximated curve arithmetic mean of the equation $\sigma=3.9353 \mathrm{~m}$.

The relative extended uncertainty $U_{L I F}^{\prime}$ which is attributed to functional dependence (4) is taken as the maximum value of the absolute value of the relative extended uncertainty $U_{L l}^{\prime}$, which is determined by the equation

$$
U_{L 1}^{\prime}=100 \cdot \frac{\left|L_{1}-L_{1}^{\prime}\right|}{L_{1}^{\prime}},
$$

The relative extended uncertainty $U_{L I F}^{\prime}$, which is attributed to functional dependence (4) taken is taken from Table 1 and is equal to $1.9 \%$.

\section{Conclusion}

In the present work, CFD-simulation of the flow of natural gas through plugged tee, which changes the flow direction, which is installed in the collector system, was carried out. As a result of simulation flow disturbance, which is caused by local resistance, was found to be smoothed in the collector system thread. Stabilization of the flow in thread of the collector unit will depend on the value of plug.

Equation (5), which allows calculating the length of the thread of the collector system to the place where distortion of natural gas flow rate, disappears to the plug length of local resistance type plugged tee, which changes the flow direction was obtained by the authors. The relative extended uncertainty $U_{L I F}^{\prime}$, which is attributed to this equation, is equal to $1.9 \%$.

\section{References}

[1] Metrology. Measurements of liquid and gas flow rate and quantity by means of orifice instruments. Part 2. Orifice plates. Technical requirements: DSTU GOST 8.586.2:2009. - Kyiv (Ukraine): Derzhspozhyvstandart Ukrainy (DSTU), 2010. - 98 pages. (National standard). (in Ukrainian)

[2] Metrology. Measurements of liquid and gas flow rate and quantity by means of orifice instruments. Part 1. Principle method of the of measurements general requirements: DSTU GOST 8.586.1:2009. - Kyiv (Ukraine): Derzhspozhyvstandart Ukrainy (DSTU), 2010. 98 pages. (National standard). (in Ukrainian)

[3] Pistun Y. Normalization of pressure differential flowmeters / Y. Pistun, L. Lesovoi. - Lviv : Publishing House of Institute of Energy Audit and Energy Carrier Accounting, 2006. - 576 p. (in Ukrainian).

[4] Rules for measuring gas and liquid flow standard primary device: RD 50-213-80. - Official Document. - Moscow: Publishing Standards. 1982. -320 p. - (The steering normative document). (in Russian)

[5] Measurement of fluid flow by means of pressure differential devices inserted in circular cross-section conduits running full - Part 1: General principles and requirements: ISO 5167-1:2003. - Geneva (Switzerland): International Organization for Standardization (ISO), 2007. 40 pages. (International standard).

[6] Measurement of fluid flow by means of pressure differential devices inserted in circular cross-section conduits running full - Part 2: Orifice plates: ISO 5167-2:2003. - Geneva (Switzerland): International Organization for Standardization (ISO), 2007. - 54 pages. (International standard).

[7] Alyamovskyy A. SolidWorks Simulation. How to solve practical tasks. - St. Petersburg, 2012. - 448 p. (in Russian)

[8] Alyamovskyy A. SolidWorks/COSMOSWorks 2006-2007. Engineering finite element analysis. - Moscow, 2007. - 784 p. (in Russian). 


\title{
Моделювання динамічних процесів руху газу в колекторних системах
}

\author{
Леонід Лесовой, Володимир Кузик \\ Національний університет “Львівська політехніка”, вул. С. Бандери, 12, Львів, 79013, Україна
}

\begin{abstract}
Анотація
Застосовуючи CFD-моделювання, автори змоделювали довжину заглушки у місцевому опорі типу заглушений трійник, який змінює напрямок потоку, за допомогою рівнянь гідродинаміки. Під час моделювання вимірювали швидкість середовища у нитці колекторної системи, у якої вхідним місцевим опором заглушено трійник, який змінює напрямок потоку. Для визначення цієї швидкості та зменшення їі спотворюваності здійснювалося моделювання колекторної системи за різних довжин заглушки. Автори визначили довжини заглушки у місцевому опорі типу заглушений трійник, який змінює напрямок потоку, за якого зникає спотворюваність епюри швидкості потоку середовища. Також отримано рівняння для розрахунку довжини нитки колекторної системи до місця, де зникає спотворюваність швидкості потоку природного газу, від довжини заглушки місцевого опору типу заглушений трійник, що змінює напрямок потоку.
\end{abstract}

Ключові слова: природний газ; колекторна система; місцевий опір; потік газу; CFD-моделювання. 